\title{
The Bible in Historical Perception and Writing of the Transcultural Iberian Societies, Eighth to Twelfth Centuries
}

\author{
Matthias M. Tischler and Patrick Marschner*
}

In stark contrast to the Bible's paramount role of being the only book declared to have "World Heritage« status by the UNESCO, research on the "Book of Books « from a transcultural perspective is an almost neglected phenomenon: Neither the Bible's relationship to other "holy or sacred « scriptures as modes of religious and cultural perceptions and transformations of the Others' world, nor its decisive role as a "normative order « in the many modes of religious, social and cultural interaction in the Euro-mediterranean world have been comprehensively studied from a historical perspective. Because of their pretension of normativity, the religious laws of this world (Tanach, Talmud, Bible and Qur'ān) were competing against and confronting each other with alternative models of perceiving time, space and history. The diverse concepts of the three monotheisms had consequences for their common but nevertheless specific narratives, genres and books of exegetical, polemical and historiographical practice; yet, we do not have clear-cut ideas of the processes of possible entanglement between these modes of perceiving and transforming the Others' history; nor do we know their exact place and value in the systems of knowledge or their retroactive effects (on either side) on the interpretations of their own religious laws. Our project intends to give answers to these basic questions based on the evidence of the Christian biblical and historiographical legacy in the transcultural frontier societies of the medieval Iberian Peninsula. We thereby change the perspective on the biblical legacy of these societies: Bible manuscripts are no longer seen as testimonies of texts or text traditions alone, but as bearers of canons: theoretical and practical concepts of history and perceptions of religious alterities. We therefore re-contextualize these perceptions of "the Others' world « within, on the one hand, the larger context of the typological thinking of preserved biblical manuscripts, their materiality and mediality; and on the other hand, in their narrative framework of the related Iberian historiographical production.

Keywords: Bible; historiography; canon; typology; identities; Iberian Peninsula; Christians, Jews and Muslims; transcultural studies

* Correspondence details: Prof. Dr. Matthias M. Tischler, Institució Catalana de Recerca i Estudis Avançats/Universitat Autònoma de Barcelona, Edifici B, Campus de la UAB, E-08193 Bellaterra. Email: Matthias.Tischler@uab.cat. Patrick Marschner, M.A., Institut für Mittelalterforschung, Österreichische Akademie der Wissenschaften, Hollandstraße 11-13, A-1020 Wien. Email: Patrick.Marschner@oeaw.ac.at. 


\section{Introduction: a changing perspective on Biblical studies in medieval history}

Traditional studies of the central role of the Bible in the Middle Ages were focused on exegesis, on biblical typology in historiography and biography, on the general role of the "Book of Books « as the central reference text of religious normativity in Jewish-Christian culture and on the relationship between the Bible and historical writing. We have learned through all this that ancient and medieval Christian historical and biographical writing could find its place only after the biblical revelation, being the recurring historical realization of its prophetic prefiguration. Yet, why did historiography always re-write this relationship between biblical prospect and historical retrospect? Our answer to this question is that Christian historiography, understood as a specific form of biblical exegesis, always tended to reformulate the written, canonized text following the norms, requirements and constraints of every new period of human history. The verification and affirmation of the world's order (ordo) always required an updated memory (memoria), all the more so when ground-breaking events and upheavals challenged the accustomed order.

Earlier research reflected this intrinsic relationship from an intracultural standpoint, but it did not qualify the role of the biblical legacy and the related historiography in frontier societies such as those of the Iberian Peninsula. One, if not the central ground-breaking event in early medieval world history was certainly Muhammad's appearance and his religious movement called Islam. Yet, what were the consequences for the conception of Christian salvation history engendered by his very existence, and what did this mean for the veracity of the Jewish-Christian Bible tradition that had never announced the coming of a last Prophet after the Messiah or Jesus Christ? With regard to the Bible being the basis of Jewish-Christian identity, the emergence of this new religious tradition produced a mighty wave of polemics and apologetics from the very first moments of Muslim identity building that was centered on the question of the reliability or falsification of the central religious books of the Jews, Christians and Muslims. The new religious situation also forced Christians to rethink the relationship between polemics, apologetics, Bible exegesis and historical writing, for, as we know, historiography was a decisive means of memory and identity building as well. Finally, we should not forget the transcultural character of the Bible itself: the edition of the Christian Bible in its Greek, Latin, Arabic and vernacular forms was and is a permanent project of processes of transfer between languages, cultures and religions with the purpose of enculturation, mission and dialogue. This perspective on the Bible opens new horizons on the construction of cultural and religious memory, of which exegesis and historiography were and are an appropriate pair of modes. The working hypothesis of our research project on the Bible and historiography in the medieval transcultural Iberian Peninsula is that the specific societal conditions of this area engendered modes of transcultural historical perception in and through its proper Bible manuscripts.

\section{The Bible as historiography: Bible manuscripts as modes of historical perception}

Let us first begin with some general statements on the Bible as a canonical text ensemble and a central reference text of religiously imbued cultures. Bible manuscripts were vivid and authentic examples of the "use of the Bible« in the Middle Ages, in which there was often demonstrated a tension between the theory and the practice of its canonicity, i.e. between a normative sequence of recommended texts and the reality of reading and copying activities. As a consequence, we have to scrutinize the sometimes erroneous understanding of the "sacral« or "holy« character of the Bible as God's revealed, inspired word and, as such, it being completely untouchable - a paradoxical conception in the "manuscript era« and its 
inevitable implications on changing texts during copy activities. Neither the Latin text nor the order of the biblical books, nor the ever-changing framework of their para-texts (prologues, arguments or chapter lists) were ever actually untouchable. A biblical book could be an authority without fixed inner and outer form, simply through permanent lecture. The late antique ecumenical Church Councils made no official decisions on the biblical canon, but gave recommendations of reading, and we see a long process of authority-building among the biblical manuscripts up to the twelfth and thirteenth centuries. ${ }^{1}$ We also have to rethink dogmatic characterizations such as "non-biblical« or even »apocryphal« texts within Bible manuscripts. ${ }^{2}$ When we consider the Bible as the constitutive and normative framework of a religiously imbued society, it is quite normal to find traces of this constitutive and normative use for the specific Christian community's general orientation in its changing contexts.

Despite these insights into the character of editing the Bible since Late Antiquity, these activities were too much qualified from an often exclusively intracultural and theological standpoint, ${ }^{3}$ neglecting the much more complex reality of the social, cultural and medial role of Bible editions in the vibrant era of cultural and religious transformations in the Euro-mediterranean world of the Early and High Middle Ages. Socially and religiously seen, editing the Bible was a permanent and total phenomenon, yet with discernible phases of intensified activities in periods of cultural and religious transformation and/or stabilization. Earlier research did not really reflect that Bible manuscripts - whether with the complete canon or only part of it - were at the end the best expression of Jewish-Christian world history.

A closer look at the medieval manuscript legacy uncovers many arguments for this chronological and even historical perception of Bible manuscripts in the Middle Ages. It is well known that the Visigothic bishop Theodulf of Orléans was, in his edition of the Bible, imitating the model of Isidore of Seville's Bible. These Bibles offer an annex of chronological and exegetical material, especially the Minor Chronicle drawn from the Etymologiae by Isidore (V 39). ${ }^{4}$ Some later Iberian Bible codices, obviously descendants of a sixth-century Visigothic edition, provide the same Chronicle, but continue its horizon up to the time of the Visigothic king Receswinth (Spanish era 690, World era 5857, CE 652). ${ }^{5}$

Another, polymorphic phenomenon is that of "prolonged" Bible manuscripts that show global, regional and local perspectives on history. The Augustinian abbey of St. Victor in Paris preserved the first volume of a full Bible edition copied in Lower Lorraine during the eleventh century. This codex opens with the Annales Leodienses and the Annales Fossenses that offer global history from a regional standpoint. ${ }^{6}$ We see further examples of this combination of globalizing Annals and full Bibles in the Premonstratensian context of the twelfth century: the two-volume Bible of Arnstein ${ }^{7}$ offers the Arnstein Annals at its beginning, following the

2 Research on the widely ignored phenomenon of "non-biblical« texts within Bible manuscripts will hopefully become one of the mighty paradigms of future Biblical Studies. We can present here only some first insights into the great potential of this perspective.

3 Fischer, Bibelausgaben.

4 Fischer, Bibelausgaben, 593 sq.

5 Ayuso Marazuela, Elementos extrabíblicos, 166-171. For other Iberian Bibles with various chronological text material see ibid., 171-175.

6 Paris, Bibliothèque nationale de France, Ms. lat. 14239.

7 London, British Library, Harley 2798-2799. 
model of the Annales Floreffienses at the beginning of the first volume of the Floreffe Bible, ${ }^{8}$ while the now three-volume Parc Abbey Bible ${ }^{9}$ presents the Annales Parchenses at the beginning of the second volume (opening with Kings). This historical perspective on the Bible is related to Peter Comestor's contemporaneous Historia scholastica, a rewritten biblical history that the finally Victorine canon enriched with exegesis and synchronized secular history, a synthesis of the Bible, exegesis and history that had already been prepared for in the new type of glossed Bible books since the late eleventh century in Laon, Paris and other places of early scholasticism.

The idea of editing Bible manuscripts with continuations of history is in fact much older: For instance, we have a Syrian Old Testament from the sixth century that complements the four books of Maccabees with the sixth book of Flavius Josephus' Bellum Iudaicum with the purpose of continuing the biblical history up to the year $70 \mathrm{CE}$ and keeping it open for an ongoing exclusively Christian history. ${ }^{10}$ And we find even other solutions: The famous Book of Armagh, an early ninth-century New Testament from Ireland, offers a continuation to the early history of the Irish and Gaulish Churches through biographical texts on St. Patrick and St. Martin of Tours. ${ }^{11}$ In the twelfth century, the Augustinian abbey of St. Victor in Paris produced a whole collection of biblical and patristic manuscripts of comparable codicological size, and paleographical and artistic data. ${ }^{12}$ Used in the refectory, this collection shows that biblical exegesis was the means to understanding the biblical canon in its internal and external history, and that unveiling the historical sense of the Bible and writing its history were two activities inextricably bound together.

All these phenomena make us aware that the Bible in its individual parts had always had the potential of continuing the Jewish-Christian history it so far represented up to the first century alone.

We can discover comparable intracultural, but also transcultural phenomena of integrating chronological and historical text material in the Iberian biblical legacy, as the following examples of local and regional settings of global Jewish-Christian history show. In the Visigothic Bible of Santa María y San Martín de Albares from $920,{ }^{13}$ the deacon John has copied between Job und Tobit a short Vita S. Froilani that depicts bishop Froilan († 905), the patron saint of the diocese of Léon, as a follower of the model of Job as God's perfect servant. The Visigothic Bible of San Miquel de Escalada, which was produced in San Pedro y San Tomás de Valeránica in the year $960,{ }^{14}$ shows texts on the archangel Michael, among them an early testimony of the famous apparition of the archangel on Monte Gargano copied at the end of the tenth century, on fol. 12v-13r and 11r. The already twelfth-century Carolingian Bible of Huesca Cathedral, ${ }^{15}$ a Giant Bible, is virtually upgraded with biographical, historical and juri-

Paris, Bibliothèque nationale de France, Ms. lat. 14395, Paris, Bibliothèque Mazarine, Ms. 47, Paris, Bibliothèque nationale de France, Ms. lat. 14396, Paris, Bibliothèque nationale de France, Ms. lat. 14245, II, etc. 
dical texts referring to the history of the diocese of Huesca. At the beginning are copied texts in memory of the venerated local Mozarabic bishop Vincent of Huesca. In addition to that, at the beginning, in the middle and at the end of the manuscript are copies of six documents and texts, among them the famous Divisio Wambae and two papal charters. The Vallbona Heptateuch, ${ }^{16}$ written in Catalan Gothic minuscule in the first half of the thirteen century was used for public lectures in the Cistercian female convent. Later on, a hand has added on the empty last pages of the final quire a copy of the Life of Martha of Tarascon, revealing the religious identity and spirituality of this important Catalan convent of noble Cistercian women.

These examples of "living with the Bible " prompt us to revisit older qualifications of non-biblical (non-canonical, apocryphal) texts in Bible manuscripts, because they are excellent indicators of local chronological and historical thinking, on the one hand, and on the other, of regional availabilities and interests of rare text material at the very moment of production. But there are even more complex concepts to discover. The Lleida Bible, ${ }^{17}$ for instance, offers an interesting example of chronological orientation. Between the historical books and the Prophets and Maccabees, there is a double side with canon tables that synchronize the reigns of the two kingdoms of Israel and Judah with the Empires of the Babylonians, Medes and Persians up to the Macedonians under Alexander the Great. Yet, we read here also the chronological order of the Prophets, so that these reorganized data build a bridge between the historical and prophetical books that gives chronological orientation and continues the story just up to the time this particular Bible was produced around the year 1165 (Fig. 1).

Yet, this Bible also offers insight into the wider transcultural background of its time of production: at its very center, between David's Psalter and Salomon's books of Wisdom, it offers a combination of eschatological text material (an overview by St. Jerome on the 15 signs before the Last Judgement and a tract on the Antichrist) and the Tiburtine Sibyl (Fig. 2). The latter text narrates world history, structured in nine ages (generationes), and pays particular attention to the history of the Roman Empire and its last ruler, the "Last Emperor ", and to Christ's birth, life and death (in the middle of the text) respectively. Being available in Spain since the middle of the eleventh century, ${ }^{18}$ this text is also transmitted in other Northern Spanish Bibles: originally in Calahorra in 1183, where the part concerned here is today fragmented, ${ }^{19}$ in San Millán de la Cogolla at the end of the twelfth/beginning thirteenth century, ${ }^{20}$ and in Vic in $1273 .{ }^{21}$ In addition to this panorama of transmission, the same text was also used for the illustrations of the final eschatological parts of two famous picture Bibles from late twelfth-century Pamplona. ${ }^{22}$ Taking into account that St. Augustine

18 The oldest copy of the text, written in Visigothic minuscule, is El Escorial, Real Biblioteca de San Lorenzo, Ms. \&. I. 3., with a thirteenth-century medieval provenance Toledo, but already dated in the year 1047: Holdenried, Sibyl and Her Scribes, 182. For further copies up to the 1120s, i. a. from Spain: ibid., Appendix B, 203-206 and Conspectus of Extant Manuscripts, ibid., 177-202.

19 Calahorra, Archivo Capitular de la Catedral, Ms. 2.

20 Madrid, Biblioteca de la Real Academia de la Historia, Ms. 2 and Ms. 3.

21 London, British Library, Add. 50003. Holdenried, Sibyl and Her Scribes, 184, knows only this Bible, which is the youngest one of all mentioned Bibles.

22 Amiens, Bibliothèque municipale, Ms. 108 and Augsburg, Universitätsbibliothek, Oettingen-Wallerstein, I. 2. 40 15. 


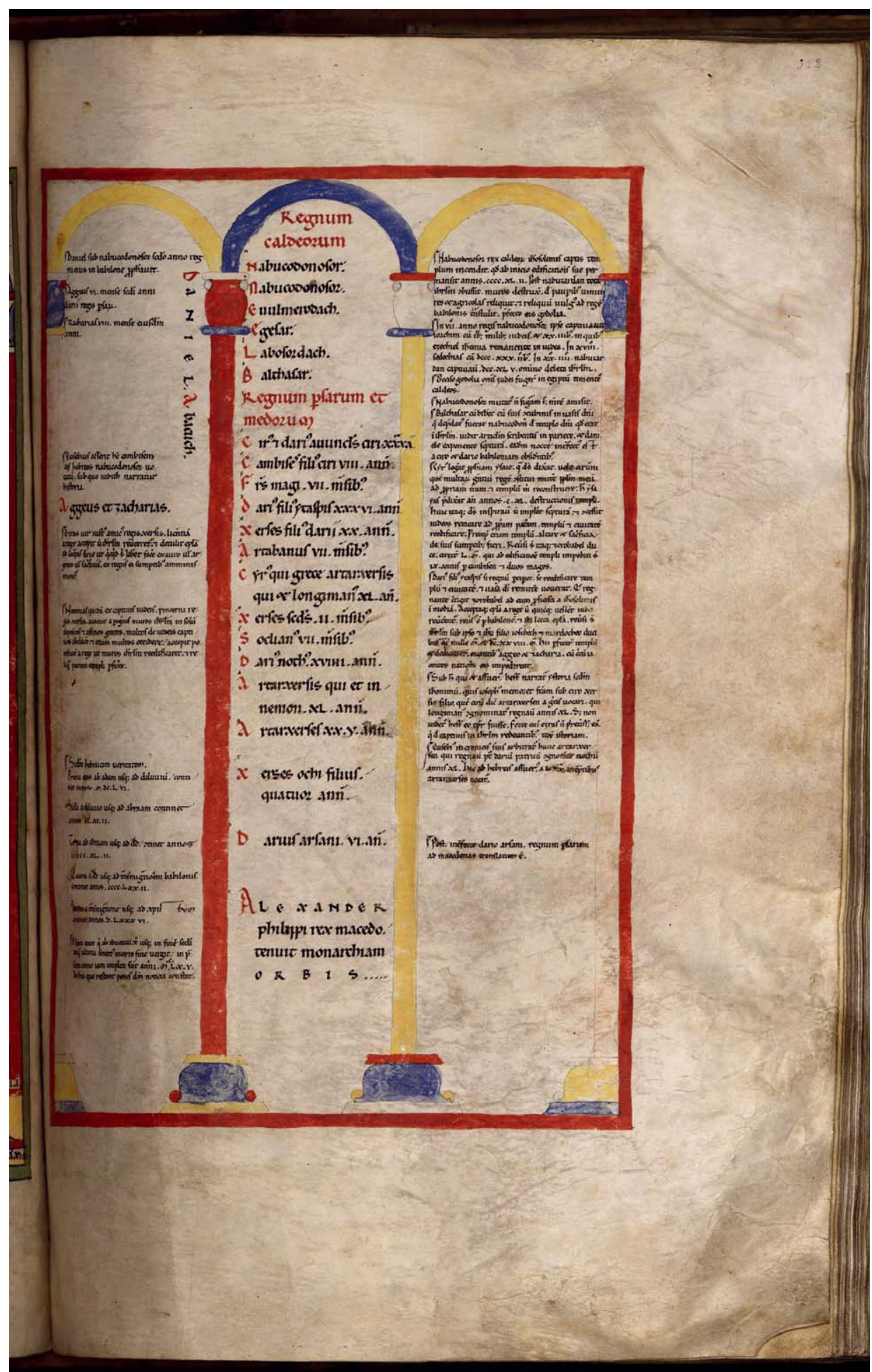

Fig. 1: Lleida, Arxiu Capitular, LC.oo61 (olim s. n.), fol. 322r 


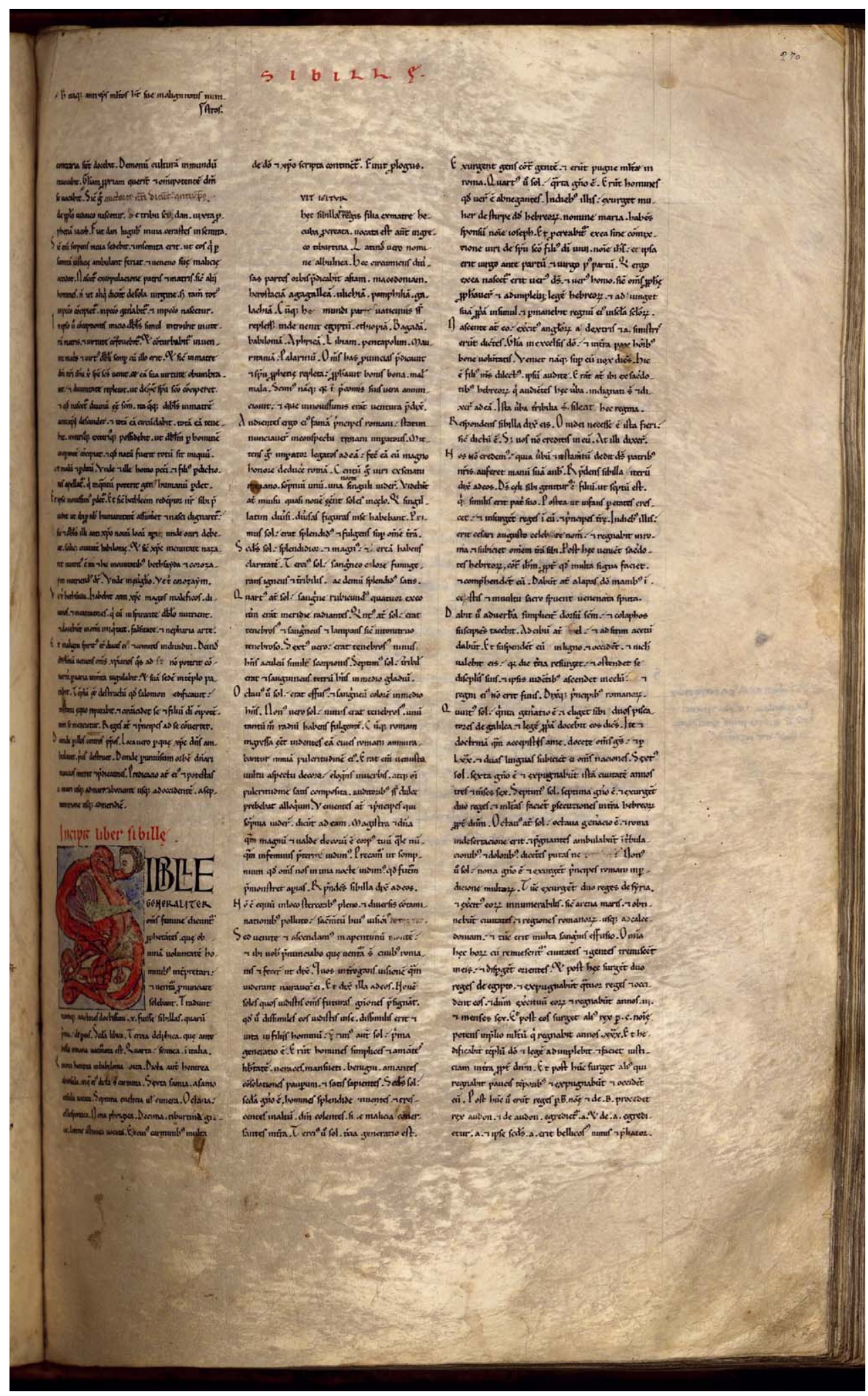

Fig.2: Lleida, Arxiu Capitular, LC.oo61 (olim s. n.), fol. 27or 
understood antique prophecies outside of the Biblical canon as testimonies of the Christian faith, and thus promoted their reception in the Middle Ages, we can suggest that we are dealing here not with a political prophecy concerning the Roman and medieval Empire, but with a Christological text transported into the specific context of some religious hotspots of the transcultural Iberian frontier societies. It was the deliberate decision of these Christian communities to perceive their current societal and religious situations from the perspective of the Tiburtine Sibyl as a prophecy of Jesus Christ's Second Coming.

\section{Pandects and multi-volume editions}

Even without these specific texts set within biblical contexts, we should not forget that re-editing the Christian Bible in the transcultural Iberian world meant establishing anew the best possible reference system of normative orders. Yet, earlier research had not actually realized that the world of the Iberian Bible was a fragmented one in a double sense. The transmission of old Bibles from late antique and Visigothic times, and the production of new Bibles from the later eighth century onwards were situated in a scattered, if not fragmented Christian society within an Islamic context; moreover, many of these earlier and new Bibles, especially those from medieval Catalonia, have survived only in a fragmentary state. ${ }^{23}$ At any rate, this specific situation prevented more intensive research and thus fascinating new insights into a complex network of text transmission and identity building in the various regions of the transcultural Iberian world. Current fieldwork in the Iberian and non-Iberian archives and libraries nevertheless shows ways of how, through typological and medial observations on manuscript production, we can identify in a fairly secure manner many missing pieces and integrate these forgotten or neglected puzzle-pieces into the master narrative of a still very "Northern Spanish" story of the Iberian Bible tradition, one that has been too much focused on the production of Visigothic and Romanesque Bible pandects from Asturias, León and Old-Castile between the eighth and twelfth centuries. The paradoxical consequence of this basic work on manuscripts is that the rich fragmentary transmission is exactly what enables us to deconstruct a petrified narrative that was mainly built on well-preserved and thus selected material evidence alone. In order to break up this narrative, some further central Iberian phenomena from medieval Catalonia have to be implemented into our new narrative: we need to rethink the strong role that the Carolingian text and manuscript tradition of the Bible played in this middle ground between Italy, France and other regions of the Iberian Peninsula. We see its importance for instance in the still under-studied Urgell Bible (Fig. 3), but also in many other barely known manuscripts from this region, where Urgell, Girona, Ripoll and Vic were the most productive centers active from the ninth and tenth centuries onwards. What is not yet clear is the exact role that the Church of Narbonne played in the transmission of the biblical text in Catalonia. Moreover, we would not be surprised if more detailed research on the Vulgate text versions would show that their channels of transmission 


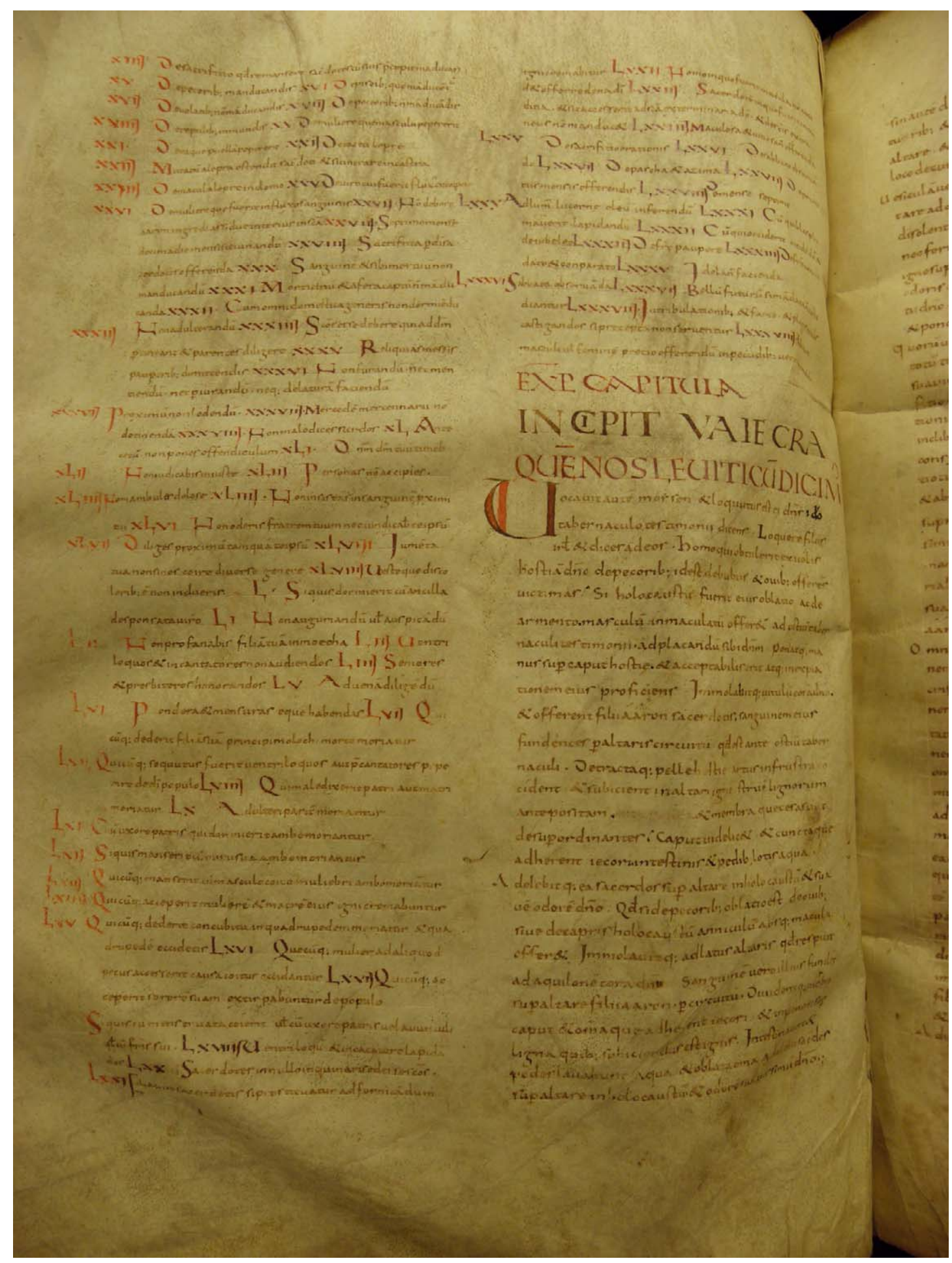

Fig.3: La Seu d'Urgell, Biblioteca Capitular, Ms. 1.997, I, fol. $7 v$ 
began in Italy, Burgundy and the Northern parts of the Western Frankish realm.

Another focus of research must lie in the various medial representations of the Bible texts: the size, the page design and the inner organization of the manuscripts. For instance, the production of Giant Bibles began already in Catalonia in the early eleventh century, hence decades before the well-known production of the famous Italian Giant Bibles. ${ }^{24}$ These Catalan Giant Bibles, whose production center certainly was the late Carolingian abbey of Ripoll, were beacons of a cultural and religious renewal in the backyard of the movement we call the "Reconquista«. Their tremendous size, elaborate page-design and rich illumination of central stories of the Bible (especially of the Old Testament) certainly displayed a counter-model of what was the dominant religious law and reference text in Southern parts of the Iberian Peninsula: the Qur'ān. We currently know three magnificent Ripoll Bibles, one copy made for the abbey itself, ${ }^{25}$ another produced for Sant Pere de Rodes,${ }^{26}$ and a third given to Sant Miquel de Fluvià (near Figueres), of which fragments are preserved today in several Catalan archives and libraries (Fig. 4). ${ }^{27}$ Yet, there must have been further Giant Bibles made in Catalonia, as we can deduct from scattered fragments. One found in the small episcopal see of Solsona - a late eleventh-century fragment of the Acts of Apostles - bears the medieval folio number .ccccxxxv.; this allows us to say that it is the remainder of a Giant Bible of certainly more than 440 leafs, following in size and page-design the famous Carolingian model of the two-columned Tours Bibles (Fig. 5).

The traditional focus on single-volume Bible editions has produced the negative effect that the much more common editions in several volumes remained a widely under-studied phenomenon. This is not only true for Catalonia, but for the entire Iberian Peninsula. Was Ripoll the only Iberian production center of Giant Bibles, or did this and other cultural centers produce the new Romanesque Bible manuscripts of the twelfth century as well? For answering these questions, we need more codicological and paleographical comparison of the entire Iberian material, which amounts to hundreds of manuscript items already known, but not really evaluated; and in combination with that we require a systematic evaluation of the rich tradition of well-documented donations of manuscripts - especially rich in medieval Catalonia - and of the catalogues of medieval Iberian libraries and book collections in order to develop a much more precise panorama than we have today of the biblical legacy of the whole Peninsula.

24 The perspective on comparable Bibles in other European countries and regions will revise the well-established but too narrow narrative focused exclusively on the well-known Italian Giant Bibles; see even the latest publication on this topic by Togni, Bibles atlantiques.

25 Città del Vaticano, Biblioteca Apostolica Vaticana, Vat. lat. 5729.

26 Paris, Bibliothèque nationale de France, Ms. lat. 6.

27 Barcelona, Arxiu de la Corona d'Aragó, Fragm. 322 and Montserrat, Arxiu i Biblioteca del Monestir, Ms. 821/IV and Banyoles, Arxiu Comarcal del Pla de l’Estany, Colleció de manuscrits, 1. 


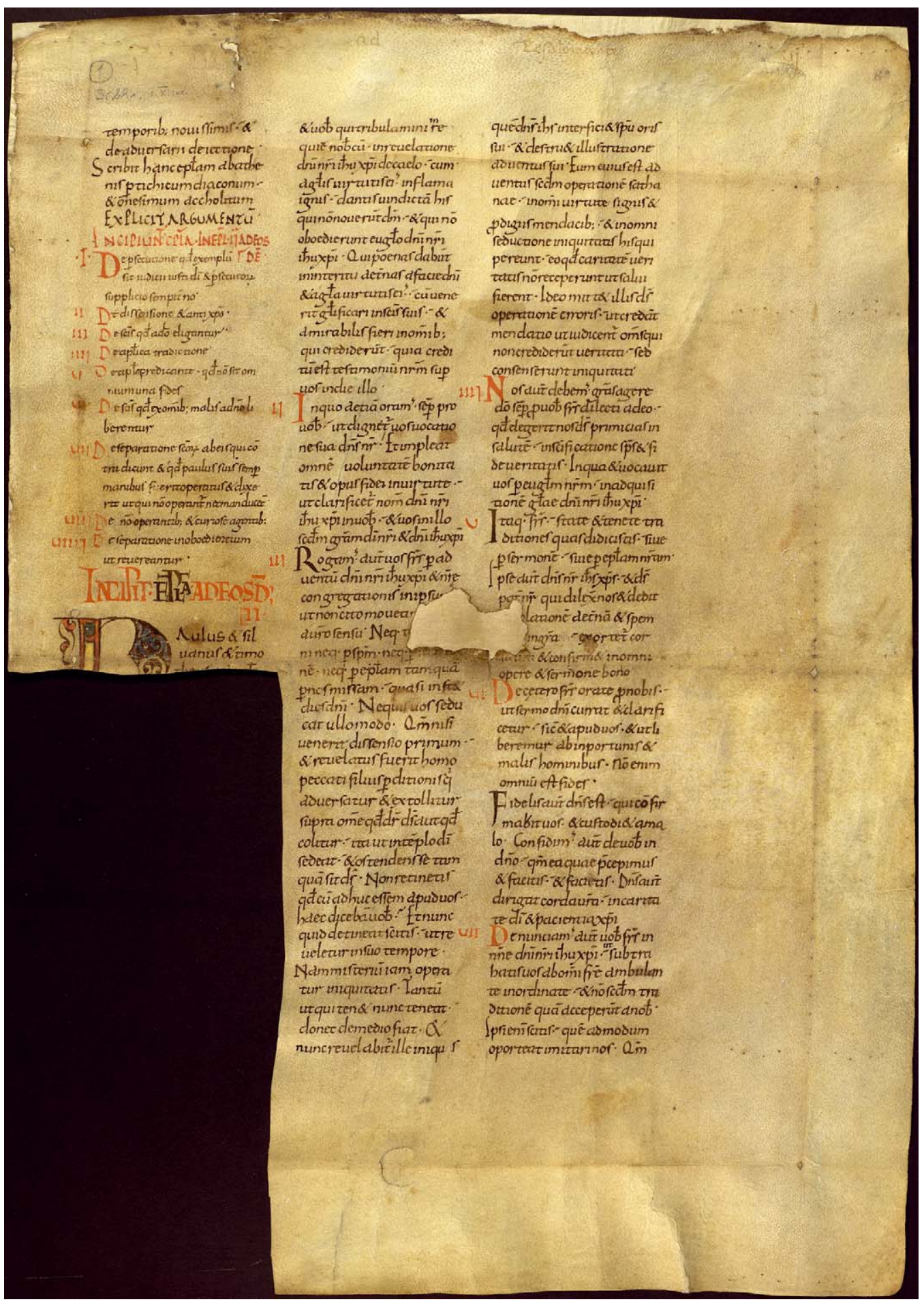

Fig. 4: Banyoles, Arxiu Comarcal del Pla de l'Estany, Colleció de manuscrits, 1, recto 


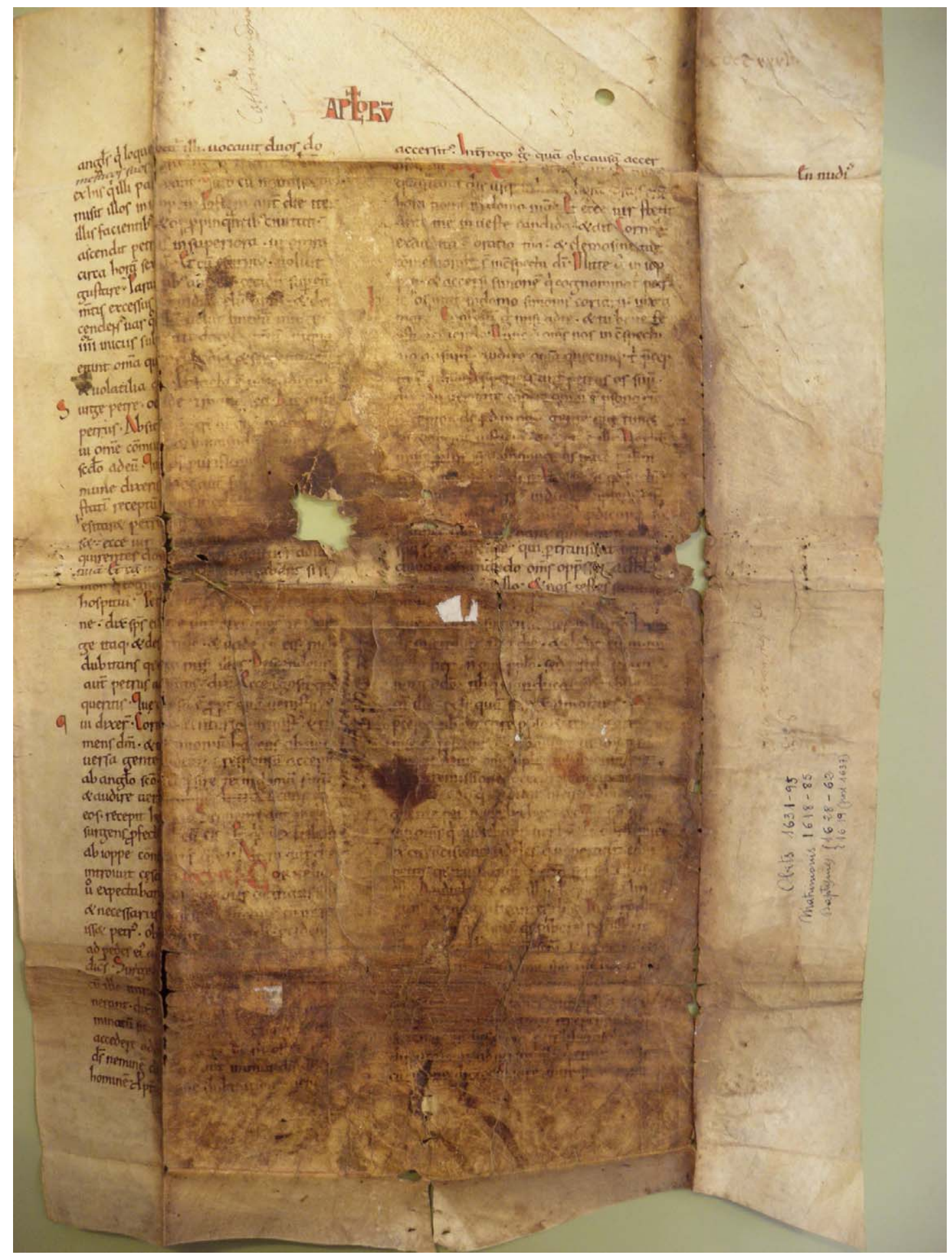

Fig. 5: Solsona, Arxiu Diocesà, Còdex 82, fol. 1 r 


\section{The Bible in post-conquest Iberian historical writing}

The Christian-Latin chronicles written in the Iberian Peninsula after the Umayyad invasion offer an immense amount of biblical elements. While eighth-century chronicles from the South of the Peninsula show less biblical content, the presence of the Bible in historical writing increases during the ninth century. The manner in which the Bible appears in these chronicles seems to be more than simple comparisons of contemporary circumstances with biblical episodes. It seems more likely that the chroniclers favoured specific forms of both biblical exegesis and typology. This manner of reading the Bible helped them to understand their situation, to interpret the events of the world they experienced, and to find modes of identification of both themselves and the cultural and religious Other. The Bible was the Christian reference system par excellence by which to describe and decipher the events and protagonists of recent Iberian history under Muslim control that are recounted in these chronicles. This could only work with the tool of typology, a specific way of representing history and which was used by the chroniclers. Systematic research into this phenomenon of biblical appearances in the Christian-Iberian chronicles from the eighth to the twelfth centuries, and the reconstruction of the chroniclers' underlying world view, are the core issues of our research on Christian historical writing in the transcultural Iberian societies and their progressing multiple identities.

Post-conquest Christian historical writing in the Iberian Peninsula has been investigated intensively since the 1930s, mostly from the point of view of national history. Spanish scholars especially have attended to this subject, ${ }^{28}$ mainly focusing on the political contents of the chronicles that emerged during the centuries after the Umayyad conquest of the Peninsula. Studies of the famous chronicles of Asturias, known as the "Asturian Cycle« or the "Asturian testimonials", were published not only by Spanish and French but also by German researchers in the 1980 s. $^{29}$ With Islam being increasingly present in Western media in the new millennium, interest in transcultural issues in history, especially encounters between Christians and Muslims in the medieval past, has also increased. Research in the field of transcultural medieval history focusses particularly on the mutual perception of different religiously imbued cultures, but also on their conflicts and their coexistence; in the case of the Iberian Peninsula, earlier research called this "convivencia. « ${ }^{30}$

The Christian chronicles of the post-conquest centuries have already been intensively explored, but none of these studies looked close enough at the biblical elements in these historical works. ${ }^{31}$ Hence, an important element for our knowledge of this transcultural era of the Iberian Peninsula is missing. If the Bible was central for the depiction of the cultural and religious Other, then it is absolutely essential to understand biblical appearances in historical writing. But we still do not know exactly how the historical writing of the medieval Iberian Peninsula really worked. Through systematic research on biblical exegesis and typology in the Iberian chronicles, we can get one step closer to answering this question, while interpreting the sources in a way they have never been questioned before.

28 Gómez Moreno, Primeras crónicas; Cotarelo Valledor, Historia crítica y documentada, 581-622; Dubler, Sobre la Crónica arábigo-bizantina; Sánchez-Albornoz, Sobre la autoridad; Díaz y Díaz, Historiografía hispana; López Pereira, Estudio crítico.

29 Prelog, Chronik Alfons' III.; Gil Fernández and Moralejo, Crónicas Asturianas; Bonnaz, Chroniques asturiennes.

30 Wolf, >Convivenciar in Medieval Spain.

31 An exception is Bronisch, who in Reconquista und Heiliger Krieg searched for the idea of "Holy War « in the Iberian Peninsula of the Christian Reconquista. He therefore focused on biblical terms that appear in historical writing. But he never systematized these biblical elements or interpreted them from a typological standpoint. 


\section{Typology}

A promising way to understand biblical elements in post-conquest Christian-Iberian historical writing is by analyzing its typology. The typological way of thinking had a long tradition in Christendom. Typological interpretations of Holy Scripture already appear in the New Testament. Furthermore, several parts of the Old Testament were understood as typological equivalents of other Old Testament passages. The basis of typology is the idea of a type, a "pre-announcement " of an event or person that will appear later, the fulfilment of the type being the anti-type. Types and anti-types substantialize Jewish-Christian salvation history. In the case of the Bible, this means that a person or event indicates a later person or event fulfilling it. So, pre-announcement and fulfilment are separated in time but connected through their common meaning.

A proof of this way of thinking as part of Christian theology is the word of Jesus in his Sermon on the Mount: "Nolite putare quoniam veni solvere legem aut prophetas non veni solvere sed adimplere ${ }^{32}$ In this sense, Jesus is the fulfilment of several Old Testament episodes. Looked at the other way around, some figures of the Old Testament were pre-announcements of him: Moses, for instance, led the Israelites out of Egypt, which can be understood as the salvation of the Chosen People; while Jesus from the time of Easter led humankind to salvation. Another example is Jonah, who spent three days in the belly of a large fish and then returned and began to preach to the people of Nineveh; likewise, Jesus lay in his tomb for three days, returned and preached to the people before going heavenwards.

The same biblical principle can be found in historical writing too. While the given examples show typological thinking within Holy Scripture, it is possible to find typological links between the Bible and non-biblical, historical texts. This form of typology has been called "half-biblical« by the German philologist Friedrich Ohly. This is exactly the case in Christian-Iberian historical writing after the Umayyad conquest. For the Christian chroniclers, the Bible was their favoured reference system. By uncovering parallels between their own history and biblical history, they could show that what was written in the Bible became partly fulfilled in "Hispania " since the fall of the Visigothic kingdom. As the Old Testament tells the story of the Chosen People losing and regaining the grace of God, the chronicles tell the story of the Iberian Christians losing rule over their country and later reclaiming it. In so doing, the chronicles continue the story of salvation, connecting them typologically with both the Old and the New Testaments. For the authors of these chronicles, universal salvation history leads to the history of the Iberian Peninsula. The successors of the Visigoths - no matter if this is to be understood as the continuation of Visigothic rule or as its reinvention (»Neogothicism «) - are depicted as the new Chosen People. This works by means of displaying the invaders and the domestic population. In this perspective, a comprehensive theology of historical writing becomes discernible.

The use of biblical passages for the depiction of specific events in Iberian history was a means of adding weight to the chroniclers' statements. The Bible offered authority, and therefore history written in the setting of biblical typology appeared to be trustworthy. In any event, the chroniclers had a Christian audience that had to be convinced. The key decision for that was to show the at least partial fulfilment ${ }^{33}$ of the Bible's episodes in history.

32 Mt 5, 17.

33 Buc, Holy War, Martyrdom, and Terror, 72-77, 89, 286. 
One can see the development of the use of biblical elements throughout the centuries after the Umayyad conquest. The first chronicles after the invasion, the so-called ByzantineArabic Chronicle from $741^{34}$ and the Mozarabic Chronicle from $754^{35}$ offer only a small number of typologically relevant passages. The most obvious one asserts Muhammad's death in the Spanish era $666 .{ }^{36}$ This presumably is a hint at the Antichrist, mentioned in the book of Revelations. ${ }^{37}$ This suspicion becomes more likely if one keeps in mind all the calculations of time that can be found in this chronicle, and which comes to the conclusion that Iberia's Christians were living at the end of the sixth age of the world, which, following St. Augustine, had been prefigured in the sixth day of creation.

With increasing polemics against foreign Muslim rule, the amount of biblical elements in Christian Iberian historical writing increased. The so-called Prophetic Chronicle from 883 is especially a proof of this observation. It was seemingly influenced by the milieu of Mozarabic Christians guided by Paulus Alvarus and Eulogius of Córdoba in their intellectual struggle against Islam, and is based on a quotation adapted from the Prophet Ezekiel. ${ }^{38}$ Instead of the Chosen People facing its enemy and their God-given punishment, i. e. the people of Gog, this chronicle summons the people of Gog to face "Ishmael. ${ }^{39}$ Obviously, the prophecy from Ezekiel has been adapted to the history of the Peninsula. As the chronicler tells us, "Gog « is to be understood as the people of the Goths, which means here the successors of the Visigoths, the Asturian kingdom under Alfonse III. ${ }^{40}$ The idea of "Gog " as "Goths « is based on Isidore of Seville's work..$^{41}$ The chronicler thus combines his knowledge of the Bible and Isidore to create a new vision authorized by Holy Scripture. The chronicle claims an end of foreign domination 170 years after its beginning and connects this with a revised prophecy. Furthermore, it contains a life of Muhammad in which the prophet is depicted in a completely negative way. This vita can be understood as a piece of anti-hagiography that shall prove that Muhammad was no prophet, but an impostor, and someone who did not resurrect but simply decayed..$^{42}$ These are just a few examples that can show how polemical this chronicle is.

\section{Ethnonyms}

According to these biblical tropes, quotes and structures, the chronicles work with another element from the Bible, ethnonyms. Chosen ethnonymic terms offer the possibility to draw conclusions about the perception of the cultural and religious Other. When the invaders are called "Arabs « - which is the ethnonym most commonly used for them in the Mozarabic Chronicle - there is no biblical connection, because this term does not appear in Holy

Isidore of Seville,
Lindsay, IX ii, 89.

42 Chronica prophetica, ed. Bonnaz, 4. 
Scripture. Yet, when they are called "Saracens " - the primary ethnonym in the Chronicle of Albelda - or "Ismaelites" - the ethnonym used most frequently in the Prophetic Chronicle - there is a connection with the Bible, in fact with the story of Abraham and his sons. ${ }^{43}$ In eighth-, ninth- and tenth-century chronicles all of these ethnonyms are used synonymously. Yet the author of the Chronicle of Albelda gives the following comment on this practice: "Sarraceni perberse se putant esse ex Sarra; uerius Agareni ab Agar et Smaelite ab Smael filio Abraam et Agar. « ${ }^{44}$ This means first of all that the ethnonyms were used as synonyms; furthermore, that the invaders were actually "Ismaelites" or "Hagarenes, « but not "Saracens." This statement is important, because there is a hierarchy in the Christian exegesis of the story of Abraham and his sons which levels up Isaac towards Ismael. This view is given in St. Paul's Epistle to the Galatians, where Isaac is understood as the promised son of the free woman, Sara, whereas Ismael is the naturally born son of a bondwoman, Hagar. ${ }^{45}$ The chronicler therefore has to explain, that "Saracen « is the wrong name for a people of actually negative connotation. Unsurprisingly so, the far more polemical Prophetic Chronicle uses "Ismaelites « the most often, thus preferring a more suitable ethnonym than the author of the Chronicle of Albelda.

\section{The Asturian foundation myth}

Later, the use of the biblical ethnonyms changed again. In the Chronicle of Alfonso III from the early tenth century, the ethnonym that is used most frequently for depicting the invaders is "Chaldeans." The Chaldeans always appear as the enemies of the Chosen People in the Old Testament, and they always play the role of God's punishment for the misconduct of the Israelites. Thus, using several biblical tropes and naming the present political enemy after the people that represented God's anger against his Chosen People in the Old Testament shows that the Bible was more than a sheer medium of comparison for the author. The Bible was the authoritative reference system that offered a specific understanding of the past and present of the involved peoples, this had to be shown in a proper way. The Iberian Christians were the new Chosen People that had to do penance for their sins. This reasoning appears several times in the chronicles we have analyzed. Yet, only the Chronicle of Alfonso III gets more specific about what those sins really were: It was the Visigothic king Wittiza, who broke up councils, had many wives and forced the bishops, priests and deacons to have wives too. This resulted in "Hispania's« decline. ${ }^{46}$

The founding myth that is contained in the Chronicle of Alfonso III contributes to the history of salvation too. Pelayo, the former sword bearer of both Wittiza and the last Visigothic king Roderic (Fig. 6), led a rebellion against the invaders. In the mountains of the very North of the Peninsula, he was hiding in a cave that is known as "Covadonga". A superior number of hostile Chaldeans besieged Pelayo and his rebels, but trusting in God he was able to defeat them, and those who were not killed by the sword fled and died when a landslide buried them alive. The chronicler himself offers an interpretation for this episode: "Non istud miraculum inane aut fabulosum putetis, sed recordamini quia qui in Rubro Mari Aegyptios Israelem 


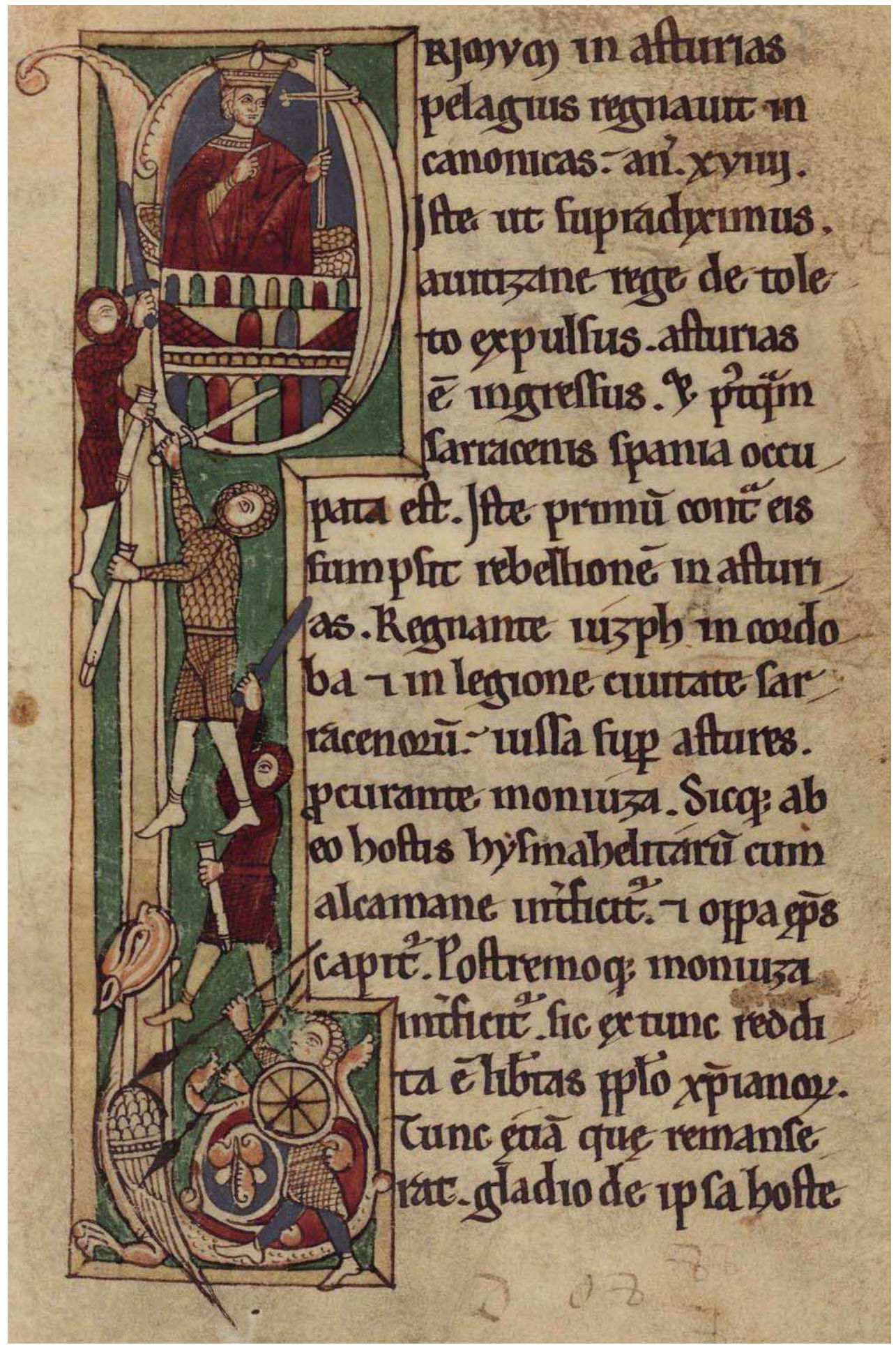

Fig. 6: Madrid, Biblioteca nacional de España, Ms. 2805, fol. $23 r$ 
persequentes demersit, ipse, hos Arabes Ecclesiam Domini persequentes, immensa montis mole oppressit. « ${ }^{47}$ The invaders are depicted in the role of the Egyptians, whereas the rebels around Pelayo are the Chosen People guided by a second Moses.

In this chronicle, the word "Pagans", used as an expression for the invaders of the Iberian Peninsula, appears for the first time. This term will later be used most frequently in the early twelfth-century Historia Silensis. No doubt, in the course of the five centuries covered, a discourse developed on the cultural and religious Other that can be deciphered from the biblical setting of the historical writing.

Our ongoing research will focus on further Christian Iberian chronicles until the end of the twelfth century. Based on the analysis of these chronicles and their possible influences, we should then be able to systematize the intertextual relationship between them and to highlight in detail the development of the discourse on the cultural and religious Other in the medieval Iberian Peninsula. A synthesis of the knowledge of these chronicles will provide deeper insights into the intellectual landscape of the transcultural medieval Iberian societies.

\section{Iberian Bible manuscripts and historical production: the common intellectual background of Reconquista in transcultural medieval Iberia}

First insights into the typical profile of Iberian Bible production since the eighth century raise the question of reliable statistical data in relation to the hazard and fate of manuscript transmission. We assume that the profile of production, reception and perception of specific biblical books or groups of books will open a common horizon of interests. The ground-breaking changes in the relationship between Christians, Jews and Muslims in the Iberian Peninsula between the eighth and twelfth centuries certainly produced profound effects on the neighbouring areas of Bible production, Bible exegesis and Christian historical writing. A recent overview article on biblical reception in the tenth-century Ottonian Empire could show that there was a strong relationship between preferred biblical books and passages, the current societal situation, and conceptions of time, space and history in the contemporary historical and biographical production..$^{48}$ But what was the situation in the contemporaneous Iberian world? We cannot now imagine a comparable profile of biblical production, reception and perception in the various Southern and Northern parts of the Peninsula, but must wait for the results of our ongoing research. What we can already see however, is that the historical books of the Pentateuch (or Heptateuch), of Kings and Maccabees, the anthropological books of Job and the Psalms, and especially the books of the Major and Minor Prophets obviously played an outstanding role in the Iberian Bible.

Hints at the privileged role of those particular books in the reading of the Iberian Bibles are the many traces of use and interest in specific passages. Glosses by readers and commentators tell us whole stories of living with the Bible in the transcultural Iberian societies: the Visigothic Bible of early ninth-century Oviedo, for instance, offers a rich corpus of apologetic glosses against Jews and heretics (Muslims?), but glosses also of a parenetic character in favour of the Church. ${ }^{49}$ The ninth-century Urgell Bible possesses glosses that show, for instance, an eager interest in the history of the Israelites in the books of Kings, in the exegesis of the Psalter and in aspects of religious life reflected in the Proverbs (Fig. 7). 


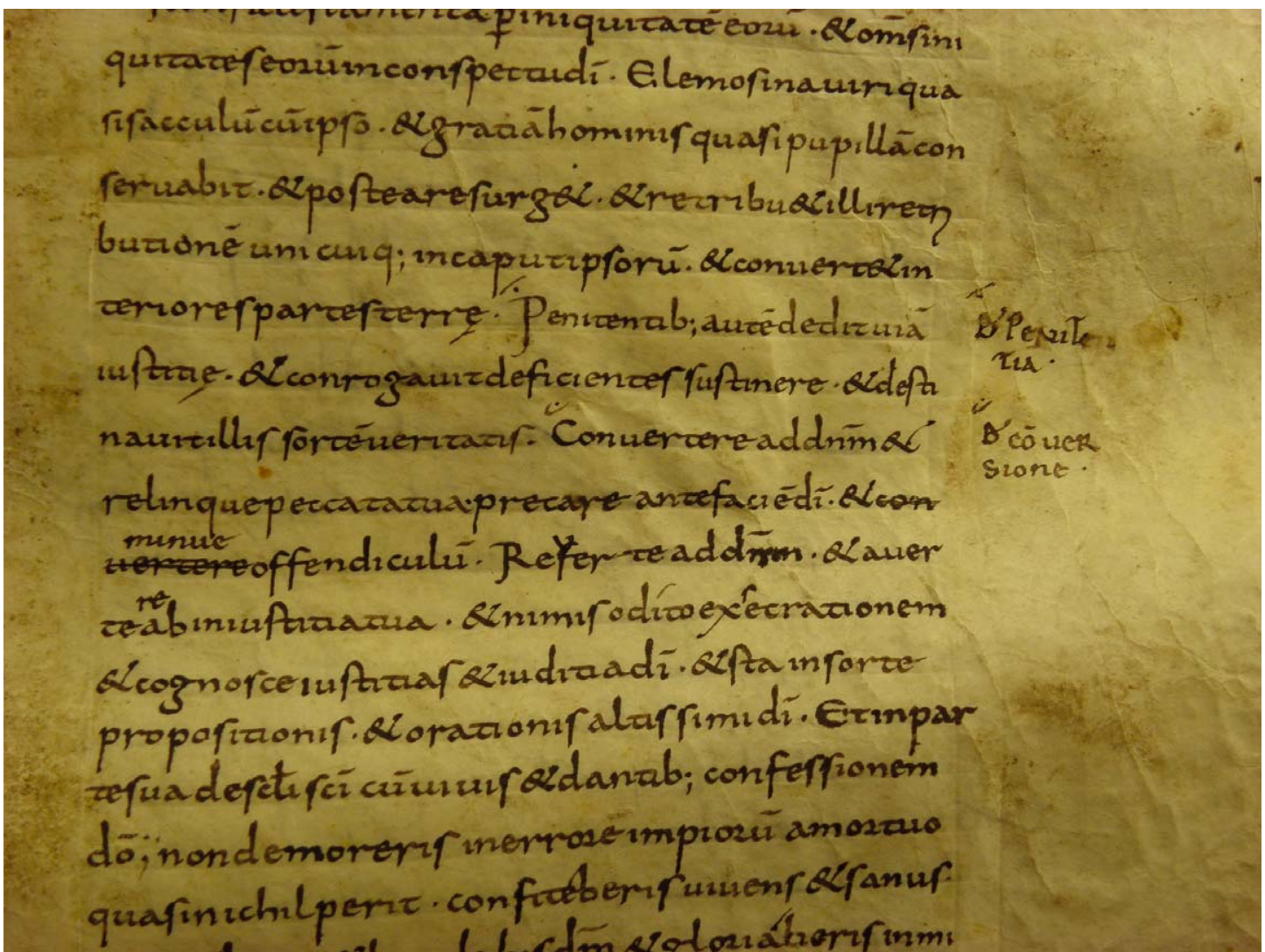

Fig. 7: La Seu d'Urgell, Biblioteca Capitular, Ms. 1.997, II, fol. 48r

Another corpus of sources showing specific text interest is offered by the rich illumination of the Northern Spanish and Catalan Bibles from the tenth and early eleventh centuries onwards. Seen against the backdrop of the Bibles from the late antique and early medieval Euro-mediterranean World, ${ }^{50}$ many cultural and religious beacons of the Iberian Peninsula developed - beside the well-known Iberian Beatus-tradition - programmes of clearly anthropological, if not Christological illustrations in reaction to the prohibition of pictures of human beings and God in Islam. We mention here only the crop of naked men fighting with the Evil in the Lleida Bible at the beginning of the Fourth book of Kings, of 1 Chronicles and in the Letters of St. Paul (Fig. 8). It was an even more explicit confession of Christian convictions when the True Cross itself found its representation and veneration in a Bible. The most prominent case for this is the collection of the pages with the Holy Cross painted and written in different colours in the La Cava Bible from early ninth-century Oviedo. We find here Holy Crosses at the beginning of the Old and New Testaments, the Psalter and the Prophetical Books. These are thus building the typological and Christological framework of the Bible (Fig. 9). 


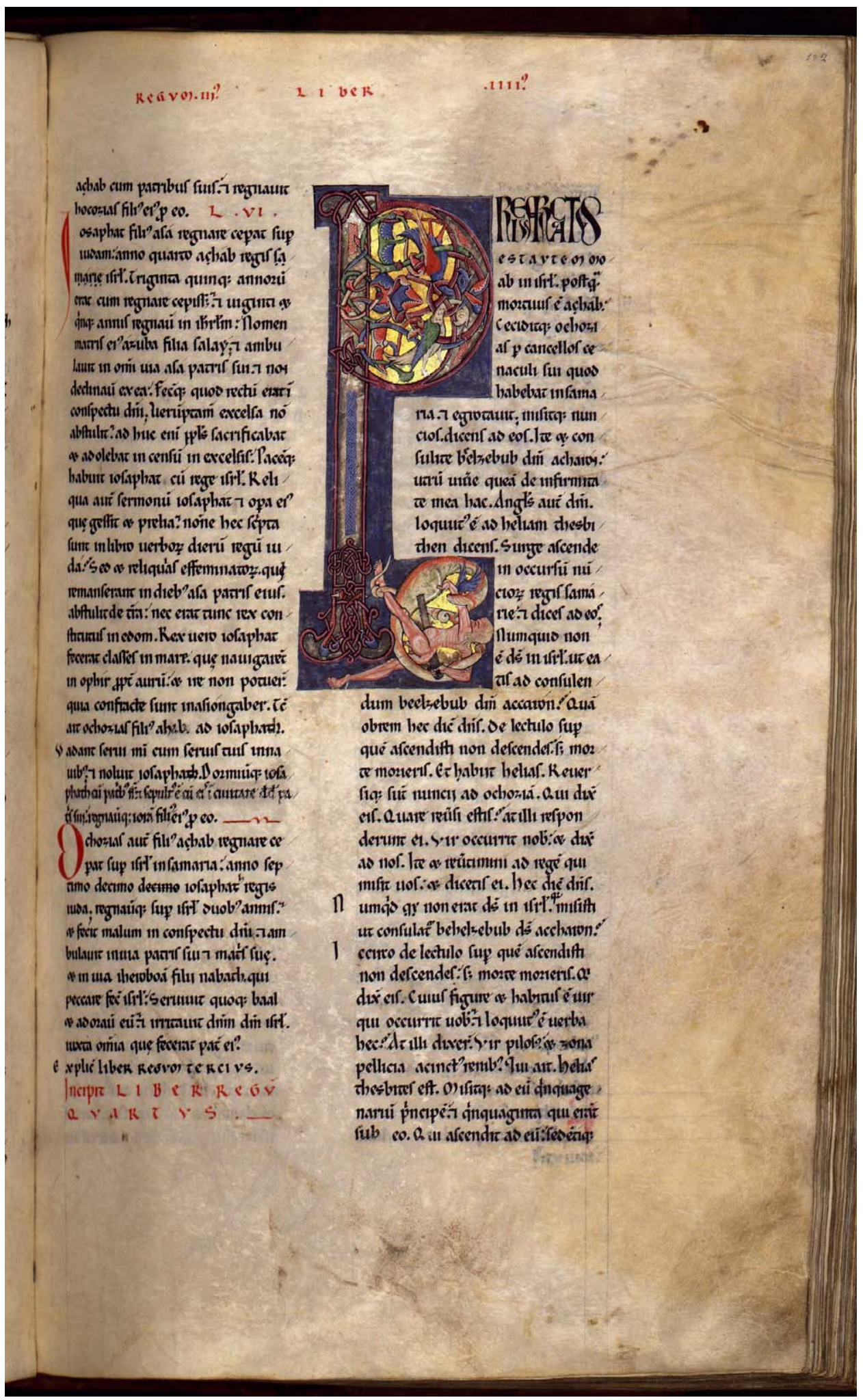

Fig. 8: Lleida, Arxiu Capitular, LC.oo61 (olim s. n.), fol. 192r 


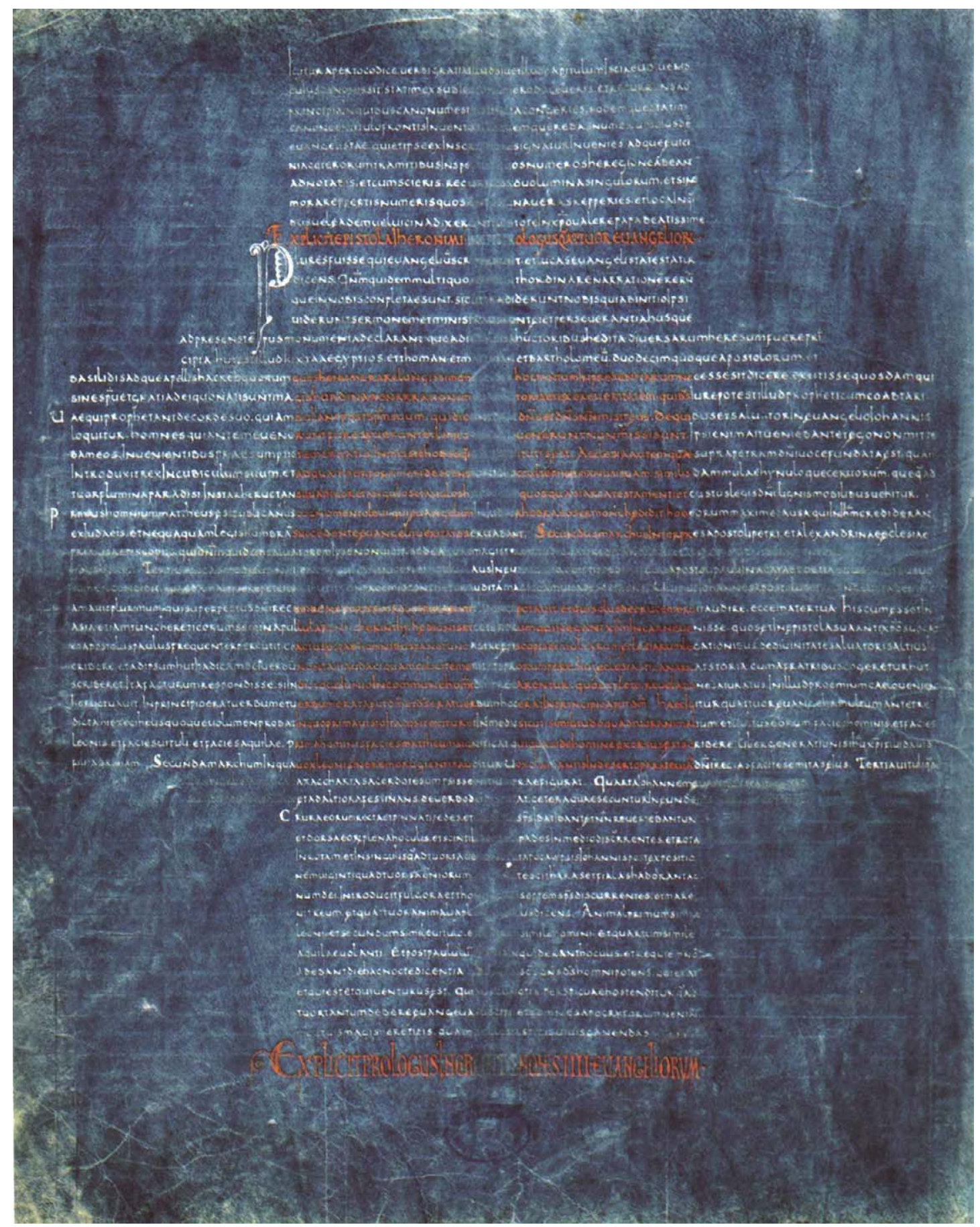

Fig. 9: La Cava de' Tirreni, Archivio e Biblioteca della Badia della SS. Trinità, Ms. Memb. I, fol. $220 \mathrm{v}$ 
Nevertheless, unsolved questions remain, especially concerning which profile of longterm transmission of biblical books the Iberian transcultural societies exactly produced. Our aims remain more modest for the moment: we are content for now to reconstruct units of biblical and historical production at individual places, so that we can gain first insights into the laboratories of that spiritual, ecclesiastical and societal movement that history for many centuries now has called the »Reconquista.«

\section{Visions for the future}

What we have presented here are pre-studies for a comparative "Handbook of the Bible in Transcultural Societies in the Euro-mediterranean World«. In this book project, preserved and reconstructed Bible manuscripts, together with parallel historical, biographical and other writing, will help us to identify the beacons of a cultural and religious renewal, a re-conquest of intellectual territory, and a reshaping of the collective cultural and religious memory of this World. This handbook should tell us the story of the rhythms of production, reception and perception of biblical books and passages answering the social and religious needs of the various transcultural societies of this globalized world. A new landscape of entangled regions and their various cultural and religious conditions should emerge and show us how this World was formed through oral and written communication, and how models of cultural and religious normativity acting against each other formed what we conceive today as a pluralized secular World order.

\section{Presentations}

Marschner, Patrick, "Bible and Biblical Exegesis in the Transcultural Iberian Historical Writing «. International Medieval Congress, Session 1308 (Social Cohesion, III: The Bible and Historiography in the Euromediterranean World), Leeds, July 8, 2015.

Marschner, Patrick, ")Nomen est adimpletio<: The Typological Meaning of Ethnic Naming in Post-Visigothic Historical Writing «, International Medieval Congress, Session 1137 (Visions of Community, II: Perceptions of the sSelf Yemen), Leeds, July 6, 2016.

Marschner, Patrick, »Biblische Typologie als Mittel zur Identifikation. Die Darstellung der Muslime in der iberischen Historiographie des 9. Jahrhunderts«. Arbeitskreis Patristik, University of Vienna, Vienna, October 21, 2016.

Marschner, Patrick, "Biblical Typology in Post-Conquest Christian Historical Writing of the Iberian Peninsula«. Universitat Autònoma de Barcelona, Bellaterra, February 23, 2017.

Marschner, Patrick, »The Interaction of the Three >Asturian Chronicles«". Texts and Identities XX - New Directions in the Early Middle Ages I, Austrian Academy of Sciences, Institute for Medieval Research, Vienna, March 3, 2017.

Marschner, Patrick, "Sünde, Strafe, Buße, Gnade. Die Gottesmoral des Alten Testaments in den Iberischen Chroniken des 9. Jahrhunderts«. Vienna Doctoral Academy, University of Vienna, Vienna, March 16, 2017.

Marschner, Patrick, "Moses in Hispania? The Battle of Covadonga and Biblical Typology in the Foundation Myth of the Asturian Kingdom «. After Empire: Using and Not Using the Past in the Crisis of the Carolingian World, c. 900-c.1050, Freie Universität Berlin, Berlin, May 17, 2017. 
Marschner Patrick, »Moses in Hispania? The Battle of Covadonga and Biblical Typology in the Foundation Myth of the Asturian Kingdom « (revised version of May 17, 2017). Princeton-Oxford-Vienna Graduate Exchange, Johannes Gutenberg-Universität Mainz, Mainz, May 20, 2017.

Tischler, Matthias Martin, »Iberian Bible Manuscripts as Modes of Transcultural Historical Perception«. International Medieval Congress, Session 1308 (Social Cohesion, III: The Bible and Historiography in the Euromediterranean World), Leeds, July 8, 2015.

Tischler, Matthias Martin, »Religious Law and History. Towards a New Perspective on Bible Manuscripts in the Transcultural Medieval Iberian Societies". The Bible in the Iberian World. Fundaments of a Religious Melting Pot, Annual Meeting of the European Association of Biblical Studies (EABS), Córdoba, July 14, 2015.

Tischler, Matthias Martin, »La tradición bíblica en la Península Ibérica desde la perspectiva tipológica. Una visión conjunta hasta el siglo xii«. A Bíblia medieval - do Românico ao Gótico (sécs. xii-xiii). Textos e imagens, produção e usos, Lisboa, Biblioteca Nacional de Portugal, November 3, 2015.

Tischler, Matthias Martin, "Bible and Historiography in Transcultural Iberian Societies, Eighth to Twelfth Centuries«, University of Michigan, Ann Arbor, April 18, 2016.

Tischler, Matthias Martin, »Religious Law and Religious History. Transcultural Perspectives on the Bible from Late Antiquity to the Middle Ages", Princeton University, April 25, 2016.

\section{Acknowledgements}

This is an interim report on the ongoing FWF Project P 27804 "Bible and Historiography in Transcultural Iberian Societies, 8th to 12th Centuries«, which presents first results and offers some new perspectives. For a detailed orientation on the project, see the description by Tischler, Bible and Historiography; idem, Biblical Legacy. In the meantime, our research on Iberian Bible transmission is especially focused on the medieval Catalan legacy within the new HERA Project 15.076 »After Empire: Using and Not Using the Past in the Crisis of the Carolingian World, c.900-c.1050 « (UNUP): arts.st-andrews.ac.uk/after-empire/ and pagines.uab.cat/unup/ (retrieved on 15 March 2017). 


\section{References}

\section{Manuscripts}

Amiens, Bibliothèque municipale, Ms. 108.

Augsburg, Universitätsbibliothek, Oettingen-Wallerstein, I. 2. 415.

Banyoles, Arxiu Comarcal del Pla de l'Estany, Colleció de manuscrits, 1.

Barcelona, Arxiu de la Corona d'Aragó, Fragm. 322.

Calahorra, Archivo Capitular de la Catedral, Ms. 2.

Città del Vaticano, Biblioteca Apostolica Vaticana, Vat. lat. 5729.

Dublin, Trinity College, MS 52.

El Escorial, Real Biblioteca de San Lorenzo, Ms. \&. I. 3.

La Cava de' Tirreni, Archivio e Biblioteca della Badia della SS. Trinità, Ms. Memb. I.

La Seu d'Urgell, Biblioteca Capitular, Ms. 1.997.

León, Biblioteca de la Catedral, Ms. 6.

León, Biblioteca de la Real Colegiata de San Isidoro, Ms. II.

Lleida, Arxiu Capitular, LC.0061 (olim s. n.).

London, British Library, Add. 14788-1479o.

London, British Library, Add. 17737-17738.

London, British Library, Add. 50003.

London, British Library, Harley 2798-2799.

Madrid, Biblioteca nacional de España, Ms. 2805.

Madrid, Biblioteca de la Real Academia de la Historia, Ms. 2.

Madrid, Biblioteca de la Real Academia de la Historia, Ms. 3.

Madrid, Museo Arqueológico Nacional, Ms. 1 (olim Ms. 485).

Milano, Biblioteca Ambrosiana, B. 21 inf.

Montserrat, Arxiu i Biblioteca del Monestir, Ms. 821/IV.

Paris, Bibliothèque Mazarine, Ms. 47.

Paris, Bibliothèque nationale de France, Ms. lat. 6.

Paris, Bibliothèque nationale de France, Ms. lat. 14239.

Paris, Bibliothèque nationale de France, Ms. lat. 14245, II.

Paris, Bibliothèque nationale de France, Ms. lat. 14395.

Paris, Bibliothèque nationale de France, Ms. lat. 14396.

Vallbona de les Monges, Arxiu del Monestir, Ms. 11.

Texts

Chronica Adefonsi III, ed. Yves Bonnaz, Chroniques asturiennes (fin ixe siècle), Sources d'histoire médiévale 20 (Paris, 1987) 31-59 (right page).

Chronica Albeldensia, ed. Juan Gil Fernández, Crónicas Asturianas, Universidad de Oviedo. Publicaciones del Departamento de Historia Medieval 11 (Oviedo, 1985) 153-188.

Chronica Byzantia-Arabica, ed. Juan Gil Fernández, Corpus Scriptorum Muzarabicorum 1, Manuales y anejos de >Emeritar 28, 1 (Madrid, 1973) 7-14.

Chronica Muzarabica, ed. José Eduardo López Pereira, Crónica mozárabe de 754: Edición crítica y traducción, Textos medievales 58 (Zaragoza, 1980) 24-130.

Chronica prophetica, ed. Yves Bonnaz, Chroniques asturiennes (fin ixe siècle), Sources d'histoire médiévale 20 (Paris, 1987) 2-9 (left page). 
Isidore of Seville, Etymologiae, ed. Wallace Martin Lindsay, Isidori Hispalensis episcopi Etymologiarum sive Originum libri XX 1-2, Scriptorum Classicorum Bibliotheca Oxoniensis (Oxford, 1911).

Isidore of Seville, Historia Gothorum Wandalorum Sueborum, ed. Theodor Mommsen, MGH Auctores Antiquissimi 11, 2 (Berlin, 1894) 267-303.

\section{Studies}

Alturo i Perucho, Jesús, Corpus biblicum medii aevi Cataloniae. Códices, fragmentos, membra disiecta y referencias librarias. Una primera aproximación, in: Agustín Hevia Ballina (ed.), Biblia y archivos de la Iglesia. Santoral hispano-mozárabe en las diócesis de España. Actas del XXVI Congresso de la Asociacón celebrado en Bilbao (12 al 16 de septiembre de 2011, Memoria Ecclesiae 38 (Oviedo, 2013) 69-114.

Ayuso Marazuela, Teófilo, Los elementos extrabíblicos de la Vulgata, Estudios bíblicos II 2 (1943) 133-187.

Bonnaz, Yves (ed.), Chroniques asturiennes (fin ixe siècle), Sources d'histoire médiévale 20 (Paris, 1987).

Bronisch, Alexander Pierre, Reconquista und Heiliger Krieg. Die Deutung des Krieges im christlichen Spanien von den Westgoten bis ins frühe 12. Jahrhundert, Spanische Forschungen der Görresgesellschaft. 2. Reihe, 35 (Münster in Westfalen, 1998).

Buc, Philippe, Holy War, Martyrdom, and Terror: Christianity, Violence, and the West, ca. 70 C. E. to the Iraq War, Haney Foundations Series (Philadelphia, 2015).

Cotarelo Valledor, Armando, Historia crítica y documentada de la vida y acciones de Alfonso III el Magno ultimo rey de Asturias (Madrid, 1933).

Díaz y Díaz, Manuel Cecilio, La historiografía hispana desde la invasión árabe hasta el año 1000, in: La storiografia altomedievale 1, Settimane di Studio del Centro Italiano di Studi sull'Alto Medioevo 17/1(Spoleto, 1970) 313-343 and 353-355 (Discussione) [repr. in Manuel Cecilio Díaz y Díaz, De Isidoro al siglo xi. Ocho estudios sobre la vida literaria peninsular, El Albir universal 3 (Barcelona, 1976) 203-234.

Dubler, César Emil, Sobre la Crónica arábigo-bizantina de 741 y la influencia bizantina en la Península Ibérica, al-Andalus 11 (1946) 283-349.

Fischer, Bonifatius, Bibelausgaben des frühen Mittelalters, in: La Bibbia nell'alto medioevo, Settimane di Studio del Centro Italiano di Studi sull'Alto Medioevo 10 (Spoleto, 1963) 519-600 [repr. in: Bonifatius Fischer, Lateinische Bibelhandschriften im frühen Mittelalter, Vetus Latina 11 (Freiburg im Breisgau, 1985) 35-100] and 685-704 (Discussione).

Gil Fernández, Juan and Moralejo, José Luis (ed./trad.), Crónicas Asturianas, Universidad de Oviedo. Publicaciones del Departamento de Historia Medieval 11 (Oviedo, 1985).

Gómez Moreno, Manuel, Las primeras crónicas de la Reconquista. El ciclo de Alfonso III, Boletín de la Academia de la Historia 100 (1932) 562-628.

Holdenried, Anke, The Sibyl and Her Scribes: Manuscripts and Interpretation of the Latin Sibyilla Tiburtina c. 1050-1500, Church, Faith and Culture in the Medieval West (Aldershot, 2006).

López Pereira, José Eduardo, Estudio crítico sobre la Crónica mozárabe de 754 (Zaragoza, 1980). Prelog, Jan (ed.), Die Chronik Alfons' III. Untersuchung und Edition der vier Redaktionen, Europäische Hochschulschriften III/134 (Frankfurt am Main, 1980).

Puig i Tàrrech, Armand, La Bíblia llatina en els països de llengua catalana fins al segle xiii, Revista catalana de teologia 28 (2003) 103-134. 
Sánchez-Albornoz, Claudio, Sobre la autoridad de las Crónicas de Albelda y de Alfonso III, Bulletin hispanique 49 (1947) 283-298 [revised version in Claudio Sánchez-Albornoz, Investigaciones sobre historiografía hispana medieval (Buenos Aires, 1967) 80-96; revised repr. in Claudio Sánchez-Albornoz, Orígines de la nación española. Estudios críticos sobre la historia del reino de Asturias 3 (Oviedo, 1975) 787-801].

Tischler, Matthias Martin, Die Bibel in Saint-Victor zu Paris. Das Buch der Bücher als Gradmesser für wissenschaftliche, soziale und ordensgeschichtliche Umbrüche im europäischen Hoch- und Spätmittelalter, Corpus Victorinum. Instrumenta 6 (Münster in Westfalen, 2014).

Tischler, Matthias Martin, Mensch und Gemeinschaft im Zeitalter der Ottonen. Die Bibel als anthropologische und soziale Orientierungsgröße zwischen dem späten 9. und frühen 11. Jahrhundert, in Christine A. Kleinjung and Stefan Albrecht (eds.), Das lange 10. Jahrhundert. Struktureller Wandel zwischen Zentralisierung und Fragmentierung, äußerem Druck und innerer Krise, Römisch-Germanisches Zentralmuseum. Tagungen 19 (Mainz, 2014) 305-328.

Tischler, Matthias Martin, Bible and Historiography in Transcultural Iberian Societies, Eighth to Twelfth Centuries, Journal of Transcultural Medieval Studies 2 (2015) 303-314.

Tischler, Matthias Martin, The Biblical Legacy of the Iberian Peninsula, Eighth to Twelfth Centuries, Seen from a Typological Standpoint, Lusitania Sacra 35-36 (2017) forthcoming.

Togni, Nadia (ed.), Les Bibles atlantiques. Le manuscrit biblique à l'époque de la Réforme de l'Église du xie siècle, Millennio medievale 110, Strumenti e studi N. S. 42 (Firenze, 2016).

Williams, John [Wesley] (ed.), Imaging the Early Medieval Bible (Philadelphia, 1999) [Philadelphia, 2002].

Wolf, Kenneth Baxter: >Convivenciar in Medieval Spain: A Brief History of an Idea, Religion Compass 3 (2009) 72-85. 